\title{
Forage breeding and management to increase the beneficial fatty acid content of ruminant products
}

\author{
R. J. Dewhurst*, N. D. Scollan, M. R. F. Lee, H. J. Ougham and M. O. Humphreys \\ Institute of Grassland and Environmental Research, Plas Gogerddan, Aberystwyth SY23 3EB, UK
}

\begin{abstract}
The declining consumption of ruminant products has been partly associated with their high proportion (but not necessarily content) of saturated fatty acids. Recent studies have focused on the less prominent fact that they are also important sources of beneficial fatty acids, including $n$ 3 fatty acids and conjugated linoleic acids. $\alpha$-Linolenic acid $(18: 3 n-3)$ is of particular interest because it also contributes to improved flavour of beef and lamb. Many recent studies showed large effects of special concentrates on levels of fatty acids in milk and meat. However, the 'rumen protection' treatments, needed to ensure a worthwhile level of fatty acid in products, are expensive. Herbage lipids are the cheapest and safest source of these fatty acids and so breeding to increase delivery of fatty acids from plants into ruminant products is an important long-term strategy. Plant lipids usually contain high levels of polyunsaturated fatty acids, particularly $18: 2 n-6$ and $18: 3 n-3$ which are the precursors of beneficial fatty acids. Whilst some plants are particularly rich in individual fatty acids (e.g. $18: 3 n-3$ in linseed), there are also useful levels in grass and clover (Trifolium Spp.). Levels of fatty acids in forages in relation to species and varieties are considered, as well as management and conservation methods. Relationships between levels of fatty acids and existing traits and genetic markers are identified. The effects of forage treatments on the fatty acid content of ruminant products are reviewed. The higher levels of polyunsaturated fatty acids in milk from cows fed clover silages show that the level of fatty acids in herbage is not the only factor affecting levels of fatty acids in ruminant products. Further effort is needed to characterise susceptibility of unsaturated fatty acids to oxidative loss during field wilting and biohydrogenation losses in the rumen, and the relative importance of plant and microbial processes in these losses. The pathways of lipolysis and lipid oxidation are reviewed and other plant factors which offer potential to breed for reduced losses are considered.
\end{abstract}

Fatty acids in milk and meat: Forage feeding: Plant breeding

The relationships between dietary fat and the incidence rates of lifestyle diseases, particularly CHD, are well-established (Enser et al. 1998). Many studies have contributed to advice that saturated fatty acids (SFA) should not supply $>0 \cdot 10$ of total energy intake, that polyunsaturated fatty acids (PUFA):SFA should be $>0 \cdot 45$, and that $n-6: n-3$ PUFA should be $<4$ for the whole diet (Department of Health, 1994). There is growing concern at the possible adverse consequences for human health of the increase in $n-6: n-3$ PUFA that has occurred from the Palaeolithic epoch $(<1)$ to the present (15-20 in many Western diets; Simopoulos, 2001).

Ruminant products have been criticised for the possible adverse effects of their SFA on human health and this factor has contributed to declining consumption. Much less attention has been given to the fact that ruminant meats often have a low fat content and that ruminant products are important sources of beneficial fatty acids, including $n-3$ fatty acids and conjugated linoleic acids (CLA). Lean beef has an intramuscular fat content of $\leq 0.05$ with approximately $0.47,0.42$ and 0.04 of total fatty acids as SFA, monounsaturated fatty acids and PUFA respectively (Moloney et al. 2001). Stearic acid (18:0) makes up 0.3 of the SFA and is considered to be neutral in its effect on plasma cholesterol ( $\mathrm{Yu}$ et al. 1995). PUFA:SFA for beef is typically low at about $0 \cdot 1$, except for double-muscled animals, which are very lean, where PUFA:SFA are typically $0 \cdot 5-0 \cdot 7$ (Raes et al. 2001). The $n-6: n-3$ for beef is beneficially low, typically $<3$ (Choi et al. 2000; Scollan et al. 2001). Milk fat typically contains $0 \cdot 69,0 \cdot 27$ and $0 \cdot 04$ 
of total fatty acids as SFA, monounsaturated fatty acids and PUFA respectively (Jensen, 2002).

Meat and dairy products from ruminants are also the main dietary sources of CLA. A number of recent studies identified health-promoting biological activities for CLA, including anti-carcinogenic activity, anti-atherogenic activity and ability to reduce the catabolic effects of immune stimulation, enhance growth promotion and reduce body fat content (Banni \& Martin, 1998).

\section{Fatty acids and product quality}

Fatty acids have important effects on a number of components of the overall quality of meat and dairy products.

\section{Health effects}

A large number of experiments have investigated the effects of supplementary fatty acids on health and these findings will not be reviewed here. The study reported by Noakes et al. (1996) provides an interesting illustration of what is possible, because it investigated effects that span the whole process from manipulating the diet of dairy cows to the health of consumers of the resulting milk and dairy products. They used rumen protection technology (see p. 331) to produce milk with 0.51 SFA (control 0.70), 0.39 monounsaturated fatty acids (control 0.28 ) and $0 \cdot 10$ PUFA (control 0.02 ). These milks and derived dairy products were fed to human volunteers. The authors suggested that the resultant 0.043 decline in plasma LDL-cholesterol levels would lead to a $0 \cdot 09$ decline in the incidence of CHD.

\section{Meat flavour}

Fatty acids are important components in the development of flavour during the cooking of meat, with both positive and negative effects of fatty acids and their oxidation products (Wood et al. 1999). Lipid breakdown products, such as aldehydes and ketones, help to explain these flavour differences (Larick et al. 1987; Elmore et al. 1997). Compounds resulting from reactions between lipid breakdown products and the products of Maillard reactions between sugars and amino acids, including thiazoles and 3-thiazolines, may also be important in explaining flavour differences (Elmore et al. 1997).

The interpretation of the effects of fatty acids on assessments of meat flavour by taste panels is more difficult because of the different production systems that predominate in different countries. Reactions to grass- or grain-fed products reflect, to some extent, the previous experience of the taste panellists (Sanudo et al. 1998). Widely different responses have been obtained to beef and lamb with increased levels of linolenic acid $(18: 3 n-3)$ in studies in the USA (Larick \& Turner, 1990), Canada (McCaughey \& Clipef, 1996; Mandell et al. 1997, 1998), Republic of Ireland (French et al. 2000) and the UK (Hewerdine et al. 2001).

\section{Spreadability of butter}

The more unsaturated fatty acids also have a lower melting point and this factor affects the spreading and processing attributes of milk products. The fatty acid composition of milk has a direct effect on the hardness (spreadability) of butter, and so this effect must be taken into account when considering increasing levels of these fatty acids in milk and butter. For example, the reduction in concentrations of fatty acids in grass during the summer months led to higher levels of SFA in butter and reduced spreadability at this time (in comparison with butters produced in spring and autumn months; Thomson \& Van Der Poel, 2000).

\section{Oxidative stability of milk and meat}

Fatty acids also have important effects on shelf-life and colour of meat. The oxidation products of PUFA catalyse the oxidation reactions that form metmyoglobin, which gives a dark-brown coloration to beef after a period of retail display. Feeding animals on diets containing fish oil resulted in meat with higher levels of lipid oxidation and greater colour deterioration than that from animals fed the other fat sources (including $18: 3 n-3$ rich linseed; Vatansever et al. 2000). Similarly, the increased levels of PUFA in milk from cows fed red-clover (Trifolium pratense) silage (RJ Dewhurst, WJ Fisher, JKS Tweed and RJ Wilkins, unpublished results; RJ Dewhurst, ND Scollan, JM Moorby and RJ Merry, unpublished results) was associated with reduced oxidative stability (Al-Mabruk et al. 2000).

\section{Manipulating fatty acids in ruminant products}

Diets containing either whole oilseeds or extracted seed oils have been widely used to manipulate the fatty acid composition of ruminant products. Rapeseed, soyabean and linseed are rich in oleic acid (18:1n-9), linoleic acid $(18: 2 n-6)$ and $18: 3 n-3$ respectively and generally result in increased levels of these fatty acids in animal products. Fish oils have been used to supply the long-chain PUFA eicosapentaenoic acid (20:5n-3) and docosahexaenoic acid (22:6n-3) and can stimulate high levels of CLA (Chilliard et al. 2000). Linseed oil (rich in $18: 3 n-3$ ) and fish oil or meal (rich in 20 $: 5 n-3$ and $22: 6 n-3)$ increased the levels of these PUFA in beef (Choi et al. 2000; Moloney et al. 2001; Scollan et al. 2001). Feeding linseed also increased levels of $20: 5 n-3$ in beef, through synthesis (chain elongation and desaturation) from $18: 3 n-3$.

The potential to increase the $n$-3 PUFA content of milk and meat is very high. Infusing $n-3$ PUFA directly into the small intestine (and hence bypassing the rumen) as linseed oil significantly $(P<0.05)$ increased the proportion of $18: 3 n-3$ compared with feeding an equivalent amount of $18: 3 n-3$ in the diet $(0 \cdot 139$ v. $0 \cdot 01018: 3 n-3$ in milk fatty acids; Petit et al. 2002). However, rumen biohydrogenation leads to the loss of most $n-3$ PUFA and the overall efficiency of transfer of $n-3$ PUFA from the diet through to the product is low (typically $<0 \cdot 05$ ). Typical values for the biohydrogenation of the major PUFA, $18: 2 n-6$ and $18: 3 n-3$ range between $0 \cdot 70-0 \cdot 95$ and $0 \cdot 85-1 \cdot 0$ respectively. Conversely, the biohydrogenation of long-chain $\mathrm{C}_{20}$ fatty acids $20: 5 n-3$ and $22: 6 n-3$ in fish oil has been shown to be much lower and is inversely related to the proportion of fish oil in the rumen. It appears that this effect is the result 
of an inhibitory action of the fish oil along the biohydrogenation pathway (Gulati et al. 1999).

Many studies have examined the effects of protecting dietary lipids from the actions of the rumen microorganisms using various methodologies, with varying extents of success. Strategies to reduce biohydrogenation have included feeding low-N diets (Gerson et al. 1986), reducing the size of feed particles (Gerson et al. 1988), feeding more mature forage (Gerson et al. 1983), removal of the fatty acid carboxyl group by using calcium salts (Barowicz \& Brejta, 2001), production of fatty acid acyl amides (Fotouhi \& Jenkins, 1992) and $\mathrm{Cu}$ supplementation (Engle et al. 2001). One of the most successful approaches involves encapsulation of PUFA in formaldehyde-treated protein (Scott \& Ashes, 1993). Using this methodology Scollan et al. (2002) observed a major increase in PUFA:SFA from 0.06 to 0.28 in beef from animals fed on concentrates containing megalac (rich in palmitic acid $(16: 0))$ and a protected lipid supplement respectively. Similarly, $18: 3 n-3$ was significantly $(P<0 \cdot 001)$ increased in the milk of cows fed a protected linseed $(0.064$ v. 0.008 in the control) in the study of Goodridge et al. (2001). Processing oilseeds is generally far less effective than feeding rumen-protected lipid supplements (Kennelly, 1996) and can lead to increased production of trans-18:1 fatty acids (mainly trans-11, i.e. vaccenic acid), as intermediates during biohydrogenation (for example, see Scollan et al. 2002).

\section{Forage effects on fatty acids in products}

Plants have the unique ability to synthesise de novo $18: 3 n-3$, which is the building block of the $n-3$ series of essential fatty acids. Fish derive their $n-3$ fatty acids from marine plankton and have been an important source used in animal feeding. However, plant sources would represent a more natural and environmentally-sustainable source. Although forages such as grass and clover usually contain $<0.05$ total fatty acids, a high proportion are present as $18: 3 n-3$ (Hawke, 1973) and this high proportion of $18: 3 n-3$ can have substantial effects on the fatty acid profiles of products.

\section{Effects of forages on a-linolenic acid in ruminant products}

The effect of forages on concentrations of $\alpha-18: 3 n-3$ in products depends on two different processes: increasing the supply of precursor $(\alpha-18: 3 n-3)$ in the crop; reducing the extent of biohydrogenation in the rumen. The effects of the forage component of diets on the level of $18: 3 n-3$ in milk fat is shown in Table 1. In each case higher levels were found in milk from cows grazing fresh herbage, which has a higher 18 : $3 n-3$ content than conserved forages (hay, silage).

Similar results have been obtained with beef cattle. Larick \& Turner (1989) reviewed a number of early studies that showed increased $18: 3 n-3$ in beef from steers grazing pasture. Their own study showed increased $18: 3 n-3$ in muscle fatty acids from steers finished with diets based on grazed grass as opposed to maize silage. Lucerne (Medicago sativa) silage has a higher content of $18: 3 n-3$ than highmoisture maize and led to increased levels of $18: 3 n-3$ in beef muscle (Mandell et al. 1997, 1998). French et al. (2000) suggested that confounding of dietary fatty acids and growth rates leads to difficulty in interpreting many of the earlier experiments. They adjusted diets to produce similar growth rates and increased levels of $18: 3 n-3$ in beef muscle from $7 \cdot 1$ to $11 \cdot 3 \mathrm{~g} / \mathrm{kg}$ total fatty acids when replacing grass silage and concentrates with fresh grass.

Other studies have shown the effects of forage fatty acids on beef fatty acids through the effects of different experimental manipulations. Thomson \& Van Der Poel (2000) showed that the decline in concentrations of fatty acids in grasses during the summer months was mirrored by lower levels of PUFA and CLA in milk. Duckett et al. (1993) conducted a serial slaughter experiment in which Angus $\times$ Hereford steers were taken off grass at 16 months of age and given a high-concentrate diet for various periods of time. The initial level of $18: 3 n-3$ in longissimus muscle was $9.3 \mathrm{~g} / \mathrm{kg}$ total fatty acids, but this level was reduced by half within 1 month of concentrate feeding and by a further half in the second month. Levels of $18: 3 n-3$ declined to $0.5 \mathrm{~g} / \mathrm{kg}$ total fatty acids after 5 months of concentrate feeding.

One of the most difficult challenges to address in increasing the delivery of forage PUFA into products is the general increase in the extent of biohydrogenation with increasing proportion of forage in the diet (Latham et al. 1972; Kalscheur et al. 1997; Kucuk et al. 2001;ND Scollan, MRF Lee and M Enser, unpublished results). This association is expected because of the predominant role of the fibrolytic bacterium Butyrivibrio fibrisolvens in rumen biohydrogenation (Latham et al. 1972). The effect will be exacerbated by the increased rate of lipolysis at high rumen $\mathrm{pH}$ (Van Nevel \& Demeyer, 1996). The recovery of $18: 3 n-3$ from feed into milk declined from $0 \cdot 0092$ to

Table 1. Effect of the forage component of diets on the linolenic acid content of milk fat ( $\mathrm{g} / 100 \mathrm{~g}$ total fatty acids)

\begin{tabular}{|c|c|c|}
\hline \multirow[b]{2}{*}{ Diets based on.... } & \multicolumn{2}{|c|}{ Linolenic acid content } \\
\hline & Fresh forage* & Conserved forage* $^{*}$ \\
\hline Timmen \& Patton (1988) & 0.84 (pasture) & 0.36 (grass and wheat silages) \\
\hline \multirow[t]{2}{*}{ Aii et al. (1988) } & 1.97 (grass) & $1 \cdot 46$ (grass hay) \\
\hline & $1 \cdot 34$ (grass) & $1 \cdot 13$ (grass hay) \\
\hline Hebeisen et al. (1993) & $2 \cdot 31$ (grass) & 0.45 (conserved grass) \\
\hline Kelly et al. (1998) & 0.95 (grass-white clover) & 0.25 (maize and legume silages) \\
\hline Dhiman et al. (1999) & 2.02 (grass-white clover) & 0.81 (lucerne hay; grass-white clover) \\
\hline
\end{tabular}

\footnotetext{
${ }^{*}$ White clover, Trifolium repens; lucerne, Medicago sativa.
} 
$0 \cdot 0058$ as the proportion in forage increased from $0 \cdot 18$ to 0.73 in the experiment of Kucuk et al. (2001).

\section{Effects of forages on conjugated linoleic acids in ruminant products}

The effect of forages on concentrations of CLA in products is more complicated than effects on levels of $\alpha-18: 3 n-3$. In addition to effects of precursor supply and rumen biohydrogenation, there are important effects on the activity of the $\Delta^{9}$ desaturase enzyme (stearoyl-coA desaturase) in the mammary gland or adipose tissue. Griinari et al. (2000) showed that more than half the CLA in milk are produced by the action of this enzyme on trans-11-18:1 produced in the rumen. $18: 2 n-6$ is a major precursor of cis-9, trans-11$18: 2$ (CLA) and trans-11-18:1, but $\alpha-18: 3 n-3$ acid can also be a precursor, via desaturation of trans-11-18:1. Elevated levels of $\Delta^{9}$ desaturase of grazing cattle (Yang et al. 1999) contribute to increased levels of CLA. ND Scollan, MRF Lee and M Enser (unpublished results) showed that muscle CLA in grazing steers was almost entirely due to tissue synthesis via $\Delta^{9}$ desaturase, due to the almost complete biohydrogenation of $18: 2 n-6$ and $18: 3 n-3$ fatty acids and the virtual absence of CLA in the rumen.

The effects of conservation (as hay or silage) of the forage component of diets on the level of CLA in milk fat is shown in Table 2. In each case higher levels were found in milk from cows grazing fresh herbage.

Chouinard et al. (1998) showed a reduction in CLA content of milk (from 1.14 to $0.48 \mathrm{~g} / 100 \mathrm{~g}$ total milk fatty acids) associated with the decline in fatty acid content (and perhaps other processes) associated with cutting Timothy (Phleum pratense) for silage at the early-heading and fullflowering growth stages. Turnout to grass, from diets based on grass silage and concentrates, was associated with increasing content of $18: 3 n-3$ and CLA in milk in the study of Agenäs et al. (2002), although increased levels of $18: 3 n-3$ were only transient as levels in the grass declined and grass availability became restricted. Grass availability was also an important factor in the study of Stanton et al. (1997); reducing the grass allowance from 20 to $16 \mathrm{~kg} \mathrm{DM}$ per head per d reduced CLA from 0.68 to $0.39 \mathrm{~g} / 100 \mathrm{~g}$ total milk fatty acids. Loyola et al. (2002) presented preliminary evidence of differences in the CLA content of milk from cows grazing different ryegrass cultivars, despite the similar $18: 2 n-6$ and $18: 3 n-3$ contents of the grasses.

In order to use plant breeding and crop management to increase the delivery of beneficial fatty acids from forages into milk and meat it is necessary to address two issues: the levels of PUFA in forage; the susceptibility of forage PUFA to being lost in the silo or rumen. These issues form the basis of the final two sections of the present paper.

\section{Breeding and management to increase levels of forage fatty acids}

The number and timing of cuts or grazing cycles affects the fatty acid composition of forages. The concentration of fatty acids in herbage tends to be highest in the spring and autumn, with lowest values during the summer, particularly around flowering. This effect has been noted for perennial ryegrass (Lolium perenne) by Bauchart et al. (1984) and for cocksfoot (Dactylis glomerata) and white clover (Trifolium repens latum) by Saito et al. (1969). Dewhurst et al. (2001) showed a more pronounced decline in fatty acid content for hybrid ryegrass and, particularly, for Italian ryegrass (Lolium multiflorum). There is some evidence that management that inhibits the initiation of flowering (e.g. two early cuts in the work of Bauchart et al. 1984 and nine cuts per year in the work of Dewhurst et al. 2002) will increase fatty acid levels.

Earlier studies have given a number of indications of the potential to use plant breeding to alter fatty acid levels and profiles in forages, as well as highlighting important genetic correlations and genotype $\times$ environment interactions.

Dewhurst et al. (2001) showed that fatty acid profiles were distinctive to species when the grasses received the same management (i.e. at the same cut), confirming a strong genetic basis. For example, Cocksfoot contained relatively low levels of $18: 1$ fatty acids and Timothy contained relatively high levels of $18: 2$ fatty acids. However, the differences were quite subtle and less clear when considered across cuts. Dewhurst et al. (2001) also noted highly significant $(P<0.001)$ species $\times$ cutting date interaction effects, reflecting most notably high values for Italian ryegrass in November (vegetative) and low values in July (flowering). Leaf content is very important in determining fatty acid content. After the flush of reproductive stem growth during May and June, leaf content increases to the end of the

Table 2. Effect of the forage component of diets on the conjugated linoleic acid* content of milk fat or beef muscle ( $\mathrm{g} / 100 \mathrm{~g}$ total fatty acids)

\begin{tabular}{|c|c|c|}
\hline \multirow[b]{2}{*}{ Diets based on.... } & \multicolumn{2}{|c|}{ Conjugated linoleic acid content } \\
\hline & Fresh forage $\dagger$ & Conserved forage $\dagger$ \\
\hline \multicolumn{3}{|l|}{ Milk fat } \\
\hline Timmen \& Patton (1988) & $1 \cdot 34$ (pasture) & 0.27 (grass and wheat silages) \\
\hline \multirow[t]{2}{*}{ Precht \& Molkentin (1997) } & 0.76 (grass) & 0.38 (maize and grass silages) \\
\hline & 1.05 (grass) & 0.55 (grass silage; green maize) \\
\hline Kelly et al. (1998) & 1.09 (grass-white clover) & 0.54 (maize and legume silages) \\
\hline Dhiman et al. (1999) & $2 \cdot 21$ (grass-white clover) & 0.89 (lucerne hay; grass-white clover) \\
\hline \multicolumn{3}{|l|}{ Beef muscle } \\
\hline French et al. (2000) & $1 \cdot 08$ (grass) & 0.37 (grass hay) \\
\hline
\end{tabular}

*Generally cis-9, trans-11-linoleic acid.

†White clover, Trifolium repens; lucerne, Medicago sativa. 
season, with Italian ryegrass staying stemmier for longer than hybrid ryegrass and perennial ryegrass being the least stemmy. Italian ryegrass and hybrid ryegrass had higher levels of total fatty acids and $18: 3 n-3$ in the early and late season when compared with perennial ryegrass. These effects show the potential for manipulating forage fatty acids through genetic manipulation of flowering times and flowering propensity, and highlight the importance of correct management to maximise benefits from genetic differences.

Within the perennial ryegrass varieties that were studied by Dewhurst et al. (2001), there was no evidence of an effect of ploidy in relation to levels and patterns of fatty acids. Within the vegetative material, the highest fatty acid levels were found in four varieties from the same gene pool (13.1 v. $9 \cdot 9 \mathrm{~g} 18: 3 n-3 / \mathrm{kg}$ DM; SED 0.68; $P<0.001)$. Preliminary evidence has been obtained for useful quantitative trait loci for concentrations of several of the important fatty acids in a well-characterised population of perennial ryegrass (LB Turner, unpublished results).

\section{Breeding and management to reduce losses of forage fatty acids}

\section{Lipolysis and oxidation}

Oxidation during field wilting and biohydrogenation in the rumen are the main sources of loss of herbage PUFA. In both cases the first step towards losses is lipolysis, which can be under the action of either plant or microbial lipases. Plant lipases obviously predominate in the field wilting situation, but there is also some evidence for effects of plant lipases in rumen lipolysis (Dawson \& Hemington, 1974; Faruque et al. 1974; Lee et al. 2002). The importance of oxidative losses during field drying of crops was demonstrated during haymaking (Aii et al. 1988) and silagemaking (Dewhurst \& King, 1998).

Plant lipases have important roles in plant physiology and are a potential target for plant breeding, so further work is needed to define their importance in losses of PUFA in the food chain. During natural leaf senescence, and in response to stresses such as wounding or pathogen attack, the action of lipases causes rapid release of fatty acids from membrane lipids (Thomas, 1986). These fatty acids are predominantly $18: 3 n-3$ and $18: 2 n-6$, which in plants are the main substrates for lipoxygenases. Lipoxygenases (linoleate: oxygen oxidoreductase) are a large gene family of fatty acid dioxygenases containing non-haem-Fe (for review, see Feussner \& Wasternack, 2002). They catalyse the dioxygenation of PUFA that contain a $(1 Z, 4 Z)$-pentadiene system. The hydroperoxy PUFA so generated are the substrates for at least seven different enzyme families. Many of the products, which include signalling compounds such as jasmonates and antimicrobial and antifungal compounds such as leaf aldehydes, are volatile.

The rapidity of lipolysis and oxidation of plant fatty acids can be monitored by studying the emission of volatile organic compounds (VOC) following leaf damage. In many species wounding, whether by pathogen attack or otherwise, greatly increases VOC emission. For example, in grass the emission of leaf alcohol ((Z)-3-hexen-1-ol) can be induced by physical damage to the leaf. Enhanced emissions have been shown to occur for both grass and clover after cutting and include hexenals, hexenols and 3-hexenyl acetate (Fall et al. 1999). Increased emissions have also been shown to occur during senescence and drying, e.g. after lawn mowing (Kirstine et al. 1998) and hay harvesting (De Gouw et al. 2000). Wounding (by cutting for haymaking or ensiling, or by the grazing animal) is an integral part of grassland management regimens; together with the drying of hay and grass clippings it makes a major contribution to biogenic VOC production. It is therefore important to ensure that selection for increased fatty acid content does not have the undesirable side effect of elevated VOC emission.

A reduction in the oxidative loss of fatty acids, and a concomitant reduction in VOC emissions, could be achieved by selecting for reduced activity of the lipoxygenase complex and other enzyme activities (including lipases) or for an increased threshold for induction of VOC emission.

Plant lipids are mainly associated with the thylakoid membranes of chloroplasts (Harwood, 1980), so an alternative strategy for reducing losses is to produce more resilient chloroplasts. One interesting approach is the production of 'stay-green' varieties, such as the sid mutant in Festuca pratensis Huds. that lacks one of the enzymes involved in chlorophyll breakdown (Harwood et al. 1982; Thomas \& Smart, 1993) and retains thylakoid membrane structure later in senescence than does wild-type grass. Staygreen material showed substantially reduced losses of fatty acids when artificially senesced by excision and incubation on moist filter paper in darkness (Harwood et al. 1982). This characteristic was transferred to perennial ryegrass using Festuca-Lolium intergeneric crossing procedures (Humphreys \& Thorogood, 1993). Dewhurst et al. (2002) found a small reduction in losses of fatty acids during wilting, although the effect may have been restricted by the rapid drying conditions.

\section{Rumen biohydrogenation}

The challenge of reducing biohydrogenation losses of forage PUFA is exaggerated by the higher biohydrogenating activity of the fibrolytic bacteria that are more prevalent in the rumen of forage-fed animals. The studies with protected lipids show that it is difficult to accomplish and, as yet, we have had little success. Studies with stay-green ryegrass and with red clover may offer some insight into possible future breeding and management strategies. Dewhurst et al. (2002) presented a preliminary evaluation of the effect of the staygreen trait (described earlier) on rumen function. The pattern of plasma fatty acids for lambs offered staygreen grass provides some tentative evidence for an effect of the stay-green trait on the rate of degradation of fatty acids.

Studies with clover silages (Lee et al. 2003; RJ Dewhurst, WJ Fisher, JKS Tweed and RJ Wilkins, unpublished results; RJ Dewhurst, ND Scollan, JM Moorby and RJ Merry, unpublished results) suggest some other possible approaches to increasing levels of forage PUFA in milk and meat. The increase in $18: 3 n-3$ content of milk from cows fed white-clover silage $(0 \cdot 96 \mathrm{~g} / 100 \mathrm{~g}$ total fatty acids $v$. $0 \cdot 40 \mathrm{~g} / 100 \mathrm{~g}$ total fatty acids for cows fed grass silage) was 
mainly the result of increased intake of $18: 3 n-3$, with a similar level of recovery $(0.055 v \cdot 0 \cdot 049)$. The increased rate of passage of white clover from the rumen should contribute to reduced biohydrogenation and increased recovery in products. The situation with red-clover silage is very different; rumen passage rates were very similar to those for grass silage, whilst the recovery of feed $18: 3 n-3$ into milk almost doubled to $0 \cdot 090$. Further work is needed to understand the mechanisms, whether plant or microbial, involved in this effect.

\section{Conclusions}

The level and type of fatty acids has important effects on several aspects of ruminant product quality, including healthiness, taste, texture and shelf-life. Plant lipids contain a high proportion of PUFA, associated with the thylakoid membranes of chloroplasts, and are the primary source of beneficial fatty acids in the food chain. Forage lipids are the cheapest and safest source of these fatty acids in ruminant feed sources, so breeding to increase delivery of fatty acids from plants into ruminant products is an important longterm strategy. Genetic variation and genetic tools to breed higher lipid forages have been identified. However, the situation is complicated by the large genotype $\times$ management interactions, particularly the large changes in fatty acid levels associated with flowering. The other approach to increasing the delivery of plant-derived PUFA into ruminant products is to reduce losses through lipolysis and oxidation during field wilting or rumen biohydrogenation. Differences between plants in these processes have been identified, but further research is needed to establish the relative importance of plant and microbial processes and develop strategies to reduce losses.

\section{References}

Agenäs S, Holtenius K, Griinari M \& Burstedt E (2002) Effects of turnout to pasture and dietary fat supplementation on milk fat composition and conjugated linoleic acid in dairy cows. Acta Agriculturae Scandinavica 52A, 25-33.

Aii T, Takahashi S, Kurihara M \& Kume S (1988) The effects of Italian ryegrass hay, haylage and fresh Italian ryegrass on the fatty acid composition of cows' milk. Japanese Journal of Zootechnical Science 59, 718-724.

Al-Mabruk RM, Beck NFG, Dewhurst RJ \& Faithfull NT (2000) Effect of legume silages fed to Holstein dairy cows on plasma alpha-tocopherol concentration, milk alpha-tocopherol and malonic dialdehyde in milk samples stored at $4{ }^{\circ} \mathrm{C}$ and $20^{\circ} \mathrm{C}$. Proceedings of the British Society of Animal Science p. 85. Edinburgh: British Society of Animal Science.

Banni S \& Martin JC (1998) Conjugated linoleic acid and metabolites. In Trans Fatty Acids in Human Nutrition, pp. 261-302 [JL Sebedio, editor]. Dundee, UK: The Oily Press.

Barowicz T \& Brejta W (2001) Using linseed oil and tankage grease calcium soaps of fatty acids for fattening young slaughter cattle. Roczniki Naukowe Zootechniki 29, 113-130 (in Polish, with English summary and tables).

Bauchart D, Verite R \& Remond B (1984) Long-chain fatty acid digestion in lactating cows fed fresh grass from spring to autumn. Canadian Journal of Animal Science 64, Suppl., 330-331.
Chilliard Y, Ferlay A, Mansbridge RM \& Doreau M (2000) Ruminant milk fat plasticity: nutritional control of saturated, polyunsaturated, trans and conjugated fatty acids. Annales de Zootechnie 49, 181-205.

Choi NJ, Enser M, Wood JD \& Scollan ND (2000) Effect of breed on the deposition in beef muscle and adipose tissue of dietary $n-3$ polyunsaturated fatty acids. Animal Science 71, 509-519.

Chouinard PY, Corneau L, Kelly ML, Griinari JM \& Bauman DE (1998) Effect of dietary manipulation on milk conjugated linoleic acid concentrations. Journal of Animal Science 76, Suppl.1, 233abstr.

Dawson RMC \& Hemington N (1974) Digestion of grass lipids and pigments in the sheep rumen. British Journal of Nutrition $\mathbf{3 8}$, 327-340

De Gouw JA, Howard CJ, Custer TG, Baker BM \& Fall R (2000) Proton-transfer chemical-ionization mass spectrometry allows real-time analysis of volatile organic compounds released from cutting and drying of crops. Environmental Science and Technology 34, 2640-2648.

Department of Health (1994) Nutritional Aspects of Cardiovascular Disease. Report on Health and Social Subjects no. 46. London: H. M. Stationery Office.

Dewhurst RJ \& King PJ (1998) Effects of extended wilting, shading and chemical additives on the fatty acids in laboratory grass silages. Grass and Forage Science 53, 219-224.

Dewhurst RJ, Moorby JM, Scollan ND, Tweed JKS \& Humphreys MO (2002) Effects of a stay-green trait on the concentrations and stability of fatty acids in perennial ryegrass. Grass and Forage Science 57, 1-7.

Dewhurst RJ, Scollan ND, Youell SJ, Tweed, JKS \& Humphreys MO (2001) Influence of species, cutting date and cutting interval on the fatty acid composition of grasses. Grass and Forage Science 56, 68-74.

Dhiman TR, Anand GR, Satter LD \& Pariza MW (1999) Conjugated linoleic acid content of milk from cows fed different diets. Journal of Dairy Science 82, 2146-2156.

Duckett SK, Wagner DG, Yates LD, Dolezal HG \& May SG (1993) Effects of time of feed on beef nutrient composition. Journal of Animal Science 71, 2079-2088.

Elmore JS, Mottram DS, Enser M \& Wood JD (1997) Novel thiazoles and 3-thiazolines in cooked beef aroma. Journal of Agricultural and Food Chemistry 45, 3603-3607.

Engle TE, Fellner V \& Spears JW (2001) Copper status, serum cholesterol, and milk fatty acid profile in Holstein cows fed varying concentrations of copper. Journal of Dairy Science $\mathbf{8 4}$, 2308-2313.

Enser M, Hallett K, Hewitt B, Fursey GAJ, Wood JD \& Harrington G (1998) Fatty acid content and composition of UK beef and lamb muscle in relation to production system and implications for human nutrition. Meat Science 49, 329-341.

Fall R, Karl T, Hansel A, Jordan A \& Lindinger W (1999) Volatile organic compounds emitted after leaf wounding: On-line analysis by proton-transfer-reaction mass spectrometry. Journal of Geophysical Research 104, 15963-15974.

Faruque AJMO, Jarvis BDW \& Hawke JC (1974) Studies on rumen metabolism. IX. Contribution of plant lipases to the release of free fatty acids in the rumen. Journal of the Science of Food and Agriculture 25, 1313-1328.

Feussner I \& Wasternack C (2002) The lipoxygenase pathway. Annual Review of Plant Biology 53, 275-297.

Fotouhi N \& Jenkins TC (1992) Resistance of fatty acyl amides to degradation and hydrogenation by ruminal micro-organisms. Journal of Dairy Science 75, 1527-1532.

French P, Stanton C, Lawless F, O'Riordan EG, Monahan FJ, Caffrey PJ \& Moloney AP (2000) Fatty acid composition, including conjugated linoleic acid, of intramuscular fat from 
steers offered grazed grass, grass silage, or concentrate-based diets. Journal of Animal Science 78, 2849-2855.

Gerson T, John A \& King ASD (1986) Effects of feeding ryegrass of varying maturity on the metabolism and composition of lipids in the rumen. Journal of Agricultural Science, Cambridge 106, $445-448$.

Gerson T, John A \& Sinclair BR (1983) The effect of dietary N on in vitro lipolysis and fatty acid hydrogenation in rumen digesta from sheep fed diets high in starch. Journal of Agricultural Science, Cambridge 101, 97-101.

Gerson T, King ASD, Kelly KE \& Kelly WJ (1988) Influence of particle size and surface area on in vitro rates of gas production, lipolysis of triacylglycerol and hydrogenation of linoleic acid by sheep rumen digesta of Ruminococcus flavefaciens. Journal of Agricultural Science, Cambridge 110, 31-37.

Goodridge J, Ingalls JR \& Crow GH (2001) Transfer of omega-3 linolenic acid and linoleic acid to milk from flaxseed or Linola protected with formaldehyde. Canadian Journal of Animal Science 81, 525-532.

Griinari JM, Corl BA, Lacy SH, Chouinard PY, Nurmela KVV \& Bauman DE (2000) Conjugated linoleic acid is synthesized endogenously in lactating dairy cows by $\Delta 9$-desaturase. Journal of Nutrition 130, 2285-2291.

Gulati SK, Ashes JR \& Scott TW (1999) Hydrogenation of eicosapentaenoic and docosohexaenoic acids and their incorporation into milk fat. Animal Feed Science and Technology 79, 57-64.

Harwood JL (1980) Plant acyl lipids. In The Biochemistry of Plants, vol 4. pp. 1-55 [KL Stumpf, editor]. New York: Academic Press.

Harwood JL, Jones AWHM \& Thomas H (1982) Leaf senescence in a non-yellowing mutant of Festuca pratensis. III. Total acyl lipids of leaf tissues during senescence. Planta 156, 152-157.

Hawke JC (1973) Lipids. In Chemistry and Biochemistry of Herbage, pp. 213-263 [UW Butler and RW Bailey, editors]. London: Academic Press.

Hebeisen DF, Hoeflin F, Reusch HP, Junker E \& Lauterburg BH (1993) Increased concentrations of omega-3 fatty acids in milk and platelet rich plasma of grass-fed cows. International Journal of Vitaminology and Nutrition Research 63, 229-233.

Hewerdine JS, Jones DA, Whittington FM, Enser M, Nute GR \& Wood JD (2001) Effects of grass or concentrates on muscle fatty acids and flavour in 2 sheep breeds. Proceedings of the British Society of Animal Science, p. 55. Edinburgh: British Society of Animal Science.

Humphreys MW \& Thorogood D (1993) Disturbed Mendelian segregations at isozyme marker loci in early backcrosses of Lolium multiflorum $\times$ Festuca pratensis hybrids to L. multiflorum Euphytica 66, 11-18.

Jensen RG (2002) The composition of bovine milk lipids: January 1995 to December 2000. Journal of Dairy Science 85, 295-350.

Kalscheur KF, Teeter BB, Piperova LS \& Erdman RA (1997) Effect of forage concentration and buffer addition on duodenal flow of trans- $\mathrm{C}_{18: 1}$ fatty acids and milk fat production in dairy cows. Journal of Dairy Science 80, 2104-2114.

Kelly ML, Kolver ES, Bauman DE, Van Amburgh ME \& Muller LD (1998) Effect of intake of pasture on concentrations of conjugated linoleic acid in milk of lactating cows. Journal of Dairy Science 81, 1630-1636.

Kennelly JJ (1996) The fatty acid composition of milk fat as influenced by feeding oilseeds. Animal Feed Science and Technology 60, 137-152.

Kirstine W, Galbally I, Ye YR \& Hooper M (1998) Emissions of volatile organic compounds (primarily oxygenated species) from pasture. Journal of Geophysical Research 103, 10605-10619.

Kucuk O, Hess BW, Ludden PA \& Rule DC (2001) Effect of forage:concentrate ratio on ruminal digestion and duodenal flow of fatty acids in ewes. Journal of Animal Science 79, 2233-2240.

Larick DK, Hedrick HB, Bailey ME, Williams JE, Hancock DL, Garner GB \& Morrow RE (1987) Flavor constituents of beef as influenced by forage and grain feeding. Journal of Food Science 52, 245-251.

Larick DK \& Turner BE (1989) Influence of finishing diet on the phospholipid composition and fatty acid profile of individual phospholipids in lean muscle of beef cattle. Journal of Animal Science 67, 2282-2293.

Larick DK \& Turner BE (1990) Flavour characteristics of forageand grain-fed beef as influenced by phospholipid and fatty acid compositional differences. Journal of Food Science 55, 313-317.

Latham MJ, Storry JE \& Sharpe ME (1972) Effect of low-roughage diets on the microflora and lipid metabolism in the rumen. Applied Microbiology 24, 871-877.

Lee MRF, Harris LJ, Dewhurst RJ, Merry RJ \& Scollan ND (2003) The effect of clover silage on long chain fatty acid rumen transformations and digestion in beef steers. Animal Science 76, (In the Press).

Lee MRF, Theodorou MK, Chow TT, Enser M \& Scollan ND (2002) In vitro evidence for plant enzyme mediated lipolysis in the rumen. Proceedings of the Nutrition Society 61, OC009

Loyola VR, Murphy JJ, O'Donovan M, Devery R, Oliveira MDS \& Stanton C (2002) Conjugated linoleic acid (CLA) content of milk from cows on different ryegrass cultivars. Journal of Dairy Science 85, Suppl.1, abstr.

McCaughey WP \& Clipef RL (1996) Carcass and organoleptic characteristics of meat from steers grazed on alfalfa/grass pastures and finished on grain. Canadian Journal of Animal Science 76, 149-152.

Mandell IB, Buchanan-Smith JG \& Campbell CP (1998) Effects of forage vs grain feeding on carcass characteristics, fatty acid composition, and beef quality in Limousin-cross steers when time on feed is controlled. Journal of Animal Science 76, 2619-2630.

Mandell IB, Gullett EA, Buchanan-Smith JG \& Campbell CP (1997) Effects of diet and slaughter endpoint on carcass composition and beef quality in Charolais cross steers. Canadian Journal of Animal Science 77, 403-414.

Moloney AP, Mooney MT, Kerry JP \& Troy DJ (2001) Producing tender and flavoursome beef with enhanced nutritional characteristics. Proceedings of the Nutrition Society 60 , 221-229.

Noakes M, Nestel PJ \& Clifton PM (1996) Modifying the fatty acid profile of dairy products through feedlot technology lowers plasma cholesterol of humans consuming the products. American Journal of Clinical Nutrition 63, 42-46.

Petit HV, Dewhurst RJ, Scollan ND, Proulx JG, Khalid M, Haresign W, Twagiramungu H \& Mann GE (2002) Milk production and composition, ovarian function, and prostaglandin secretion of dairy cows fed omega-3 fats. Journal of Dairy Science 85, 889-899.

Precht D \& Molkentin J (1997) Effect of feeding on conjugated cis $\Delta 9$, trans $\Delta 11$,-octadecadienoic acid and other isomers of linoleic acid in bovine milk fats. Nahrung 41, 330-335.

Raes K, Smet S \& Demeyer D (2001) Effect of double-muscling in Belgian Blue bulls on the intramuscular fatty acid composition with emphasis on conjugated linoleic acid and polyunsaturated fatty acids. Animal Science 73, 253-260.

Saito T, Takadama S, Kasuga H \& Nakanishi T (1969) Effects on fatty acid composition of lipids in cows milk by grass and legume feed (VI) Differences of effects of district and seasons, on fatty acid composition of lipids in grass and legume. Japanese Journal of Dairy Science 18, 183-189 (in Japanese, with English summary and tables). 
Sanudo C, Nute GR, Campo MM, Maria G, Baker A, Sierra I, Enser M \& Wood JD (1998) Assessment of commercial lamb meat quality by British and Spanish taste panels. Meat Science 48, 81-99.

Scollan ND, Choi N-J, Kurt E, Fisher AV, Enser M \& Wood JD (2001) Manipulating the fatty acid composition of muscle and adipose tissue in beef cattle. British Journal of Nutrition $\mathbf{8 5}$, $115-124$.

Scollan ND, Gulati S, Wood JD \& Enser M (2002) The effects of including ruminally protected lipid in the diet of Charolais steers on animal performance, carcass quality and the fatty acid composition of longissimus dorsi muscle. Proceedings of the British Society of Animal Science, p. 9. Edinburgh: British Society of Animal Science.

Scott TW \& Ashes JR (1993) Dietary lipids for ruminants: protection, utilization, and effects on remodelling of skeletal muscle phospholipids. Australian Journal of Agricultural Research 44, 495-508.

Simopoulos AP (2001) n-3 Fatty acids and human health: defining strategies for public policy. Lipids 36, S83-S89.

Stanton C, Lawless F, Kjellmer G, Harrington D, Devery R, Connolly JF \& Murphy J (1997) Dietary influences on bovine milk cis-9, trans-11-conjugated linoleic acid content. Journal of Food Science 62, 1083-1086.

Thomas H (1986) The role of polyunsaturated fatty acids in senescence. Journal of Plant Physiology 123, 97-105.
Thomas H \& Smart CM (1993) Crops that stay green. Annals of Applied Biology 123, 193-219.

Thomson NA \& Van Der Poel W (2000) Seasonal variation of the fatty acid composition of milk fat from Friesian cows grazing pasture. Proceedings of the New Zealand Society of Animal Production 60, 314-317.

Timmen H \& Patton S (1988) Milk fat globules: fatty acid composition, size and in vivo regulation of fat liquidity. Lipids 23, 685-689.

Van Nevel CJ \& Demeyer DI (1996) Influence of pH on lipolysis and biohydrogenation of soybean oil by rumen contents in vitro. Reproduction Nutrition Development 36, 53-63.

Vatansever L, Kurt E, Enser M, Nute GR, Scollan ND, Wood JD \& Richardson RI (2000) Shelf life and eating quality of beef from cattle of different breeds given diets differing in $n-3$ polyunsaturated fatty acid composition. Animal Science 71, 471-482.

Wood JD, Enser M, Fisher AV, Nute GR, Richardson IR \& Sheard PR (1999) Manipulating meat quality and composition. Proceedings of the Nutrition Society 58, 363-370.

Yang A, Larsen, TW, Smith SB \& Tume RK (1999) $\Delta^{9}$ Desaturase activity in bovine subcutaneous adipose tissue of different fatty acid composition. Lipids 34, 971-978.

Yu S, Derr J, Etherton TD \& Kris-Etherton PM (1995) Plasma cholesterol-predictive equations demonstrate that stearic acid is neutral and monounsaturated fatty acids are hypocholesterolemic. American Journal of Clinical Nutrition 61, 1129-1139. 